\title{
Education Session Design for Its Member: A Case Study of Meeting and Event Industry Association MPI
}

\author{
Xuehui Zeng \\ Event Management Department \\ Shanghai Second Polytechnic University (SSPU) \\ Shanghai, China
}

\begin{abstract}
MPI is the association for people who bring people together. It is the platform for people to meet face-to-face and empowers them to stand shoulder-to-shoulder, leading the world in professional development that advances the meeting and event industry and the careers of the people working in it. The major stakeholders are its members including event planner, service supplier, student and faculty. Research shows that in order to benefit its member in terms of learning, networking and leadership development, especially of career-enhance education, MPI designed intended MPI academy, powered the Smart Monday of IMEX America and organized World Education Congress (WEC). These education designs provide skills training, perfect education resource and the connections of its member to the industry. The education sessions produced meet the needs of the stakeholders, followed the adult learning principles with more relevant, meaningful and interactive learning experience in order to achieve the learning outcome. The education sessions designed by MPI inspire, educate and energize all those involved in meeting and event industry.
\end{abstract}

Keywords-association stakeholders; education session design; learning outcome; challenge and solution

\section{INTRODUCTION}

According to the Economic Significance of Meetings to the US Economy published by event industry council in February 2018, meetings supported a total economic impact in 2016 of $\$ 845$ billion of output (business sales), 5.9 million jobs with $\$ 249$ billion of labor income, \$446 billion of GDP (representing contribution to US gross domestic product) and $\$ 104$ billion of federal, state and local taxes. The meetings sector supported more direct jobs than many large manufacturing sectors, including machinery, food, auto, and chemicals. It sustained more jobs than the telecommunications and oil and gas extraction industries as well. Statistics shows that meetings industry has significant impact on the economy of a country. [2] Recently, the value of meetings has had an increasingly important focus for many companies. Meetings are desired and focus more on the business values for companies and participants. This has led to the growth of Strategic Meetings Management. MPI identified that Strategic

This research was supported by the Tourism Management Discipline Research Program funded by Shanghai Polytechnic University, P.R. China (Grant NO. XXKPY1607).
Meetings Management is a practice which helps companies to control their spending on meetings but also provides companies with more consistent relationships with suppliers and a more consistent quality experience. When measuring the value of meetings, three components are focused specifically on: Learning, Networking and Loyalty. [3][5] Therefore, education session design can not only in relation to cost savings, but in relation to the value or return on investment of value-add components.

\section{MEETING AND EVENT INDUSTRY ASSOCIATION MPI AND ITS FEATURES}

Meeting Professionals International (MPI) is the largest meeting and event industry association worldwide. Founded in 1972, MPI provides innovative and relevant education, networking opportunities and business exchanges, and acts as a prominent voice for the promotion and growth of the industry. MPI has a global community of 60,000 meeting and event professionals including more than 17,000 engaged members and its Plan Your Meetings audience. It has more than 90 chapters and clubs in 19 countries. The mission of MPI is to connect the global meeting and event community to learn, innovate, collaborate and advocate leading and empowering the meeting and event community to change the world. MPI focused on people and view people as the most valuable asset, dedicated to collaboration for the betterment of the community and chapters, carried out with enthusiasm and passion for the members and the success of the industry, respecting diversity to embrace and foster an inclusive business climate of respect for all peoples regardless of national origin, race, religion, gender, age, color, or disability.

\section{STAKEHOLDERS OF MPI AND THEIR EXPECTATIONS}

The name "association" implies the act of being associated for certain common purposes, whether for professional, industrial, educational, scientific, or social reasons. Gatherings such as annual conventions, topical conferences, workshops and seminars are held for the benefit of the association's membership. Other gatherings are held for the betterment of the organization. Besides providing value to the members of the association and potential recognition for the association, 
these gatherings also generate a significant revenue stream for the organization. A major difference between association and corporate gatherings is that attendance at association meetings is voluntary, not mandatory. Another difference is that the attendees are personally responsible for their registration, transportation, hotel, and related expenses. [6] Although sometimes, employers may fund the attendance of employees for the event that are work-related. Therefore, value of association meetings is very important.

The major stakeholders are its members including event planner, service supplier, student and faculty. They join MPI and expect the benefit to network that actually works, easy access to connect professionals of the industry, find better job opportunity, vendor, mentor, or new hire. They would like to enjoy career-enhancing education, since the MPI Academy offers education and certificate programs that enhance critical job skills. They hope to join local MPI chapter, take the opportunities to advance, grow for career development and become the leader of the industry.

\section{SUCCESSFUL MEETINGS AND ITS CHALLENGES IN MEETING DESIGN}

A planned occurrence or experience that facilitates participants gaining knowledge, skills, attitudes and/or behaviors is considered to be a learning event. Many meetings view learning as a focus of the meeting. Learning can be difficult to measure because it is a process and is dependent upon individuals and their environments. At meetings, learners are often diverse in terms of education level, seniority, age, tenure and thus, are at different stages for receiving, using or even interest in learning. Thus, different participants have different objectives for the meetings they attend. According to Meeting Value Research, Measuring Meeting Value Guidebook Sponsored by MPI, when gathering this data in a pre-meeting survey or during meeting registration by survey or interviews, monitor social media posts and additionally conduct a post-meeting survey, research findings reveals that participants attend the meeting mainly the for the following objectives.[3] [4] See table I

\section{TABLE I. OBJECTIVES FOR ATTENDING MEETINGS}

\begin{tabular}{|l|l|}
\hline Item No. & \multicolumn{1}{|c|}{ Objective for Attending Meetings } \\
\hline 1 & Meeting my peers \\
\hline 2 & Making new contacts \\
\hline 3 & Learning new things \\
\hline 4 & Promoting my business \\
\hline 5 & Meeting experts \\
\hline 6 & Learning how to do my job better \\
\hline 7 & Gaining professional education credits \\
\hline 8 & Looking for new business \\
\hline 9 & Looking for a new job \\
\hline 10 & Strengthening my network \\
\hline
\end{tabular}

Research also shows in 2018 Meeting Trends: Successful Meetings, providing quality meetings on limited budgets, managing safety and security risks, creating compelling meeting content, proving ROI for meetings, keeping up with the evolution of meetings technology are the top 5 issues that will be important to plan effective meetings in 2018. [1][7] Among them, as high as 54\% of compelling meeting content is considered as important factors for planning effective meetings. See table II. Most difficult challenges in creating meetings content in 2018 are listed in the research report. Creating compelling meeting content is the No. 1 difficult challenge. See table III.

TABLE II. THE TOP 5 ISSUES THAT WILL BE IMPORTANT TO PLAN EFFECTIVE MEETINGS IN 2018

\begin{tabular}{|l|l|l|}
\hline Item No. & \multicolumn{1}{|c|}{ Issues } & \multicolumn{1}{|c|}{ Percentage } \\
\hline 1 & $\begin{array}{l}\text { Providing quality meetings on limited } \\
\text { budgets }\end{array}$ & $59 \%$ \\
\hline 2 & Managing safety and security risks & $55 \%$ \\
\hline 3 & Creating compelling meeting content & $54 \%$ \\
\hline 4 & Proving ROI for meetings & $52 \%$ \\
\hline 5 & $\begin{array}{l}\text { Keeping up with the evolution of } \\
\text { meetings technology }\end{array}$ & $5 \%$ \\
\hline
\end{tabular}

TABLE III. MOST DIFFICULT CHALLENGES IN CREATING MEETING CONTENTS IN 2018

\begin{tabular}{|l|l|l|}
\hline Item No. & \multicolumn{1}{|c|}{ Challenges } & Percentage \\
\hline 1 & Creating compelling meeting content: & $65 \%$ \\
\hline 2 & $\begin{array}{l}\text { Create compelling meeting environments that } \\
\text { enhance learning: }\end{array}$ & $58 \%$ \\
\hline 3 & $\begin{array}{l}\text { Getting quality speakers and presenters: } \\
\text { Getting attendees to embrace apps and second } \\
\text { screen technologies: }\end{array}$ & $36 \%$ \\
\hline 5 & $\begin{array}{l}\text { Getting enough WiFi bandwidth to meet } \\
\text { content needs: }\end{array}$ & $31 \%$ \\
\hline 6 & $\begin{array}{l}\text { Ability to develop virtual meeting offerings for } \\
\text { your attendees: }\end{array}$ & $21 \%$ \\
\hline 7 & $\begin{array}{l}\text { Providing healthy activity options for } \\
\text { attendees: }\end{array}$ & $10 \%$ \\
\hline
\end{tabular}

\section{EDUCATION SESSIONS DESIGNED FOR MPI MEMBERS}

In order to benefit it member and meet their needs in terms of learning, networking and leadership development, MPI designed education by MPI Academy and by organizing or sponsoring event like Smart Monday in IMEX America and World Education Congress (WEC).

\section{A. MPI Academy}

MPI Academy helps to enhance the planner for meeting planning career. With hundreds of hours of free education for MPI members, the MPI Academy is a one-stop shop for meeting planning and event industry skills training, CE credits and certificate courses. Featuring online and in-person classes and webinars, it's the perfect resource for the job you have - or the job you want. 
TABLE IV MPI ACADEMY EDUCATION RESOURCES AND ITS FEATURES

\begin{tabular}{|c|c|}
\hline Education resources & Features \\
\hline Streaming & $\begin{array}{c}\text { From instructor-led online courses to virtual event } \\
\text { passes, streaming sessions offer live lessons in real } \\
\text { time anywhere, on any device. }\end{array}$ \\
\hline On-Demand & $\begin{array}{c}\text { Online webinars, certificate programs and training } \\
\text { sessions let you learn at your own pace anytime, } \\
\text { anywhere, on any device. }\end{array}$ \\
\hline In-Person & $\begin{array}{c}\text { A classroom experience, Instructor-led certificate } \\
\text { courses give you the deep-dive you need to refine } \\
\text { your skills and build your resume. }\end{array}$ \\
\hline
\end{tabular}

\section{B. Smart Monday in IMEX America}

IMEX America is America's worldwide exhibition for incentive travel, meetings and events. IMEX helps everyone in the global meetings industry to make the connections that matter, bringing the global meetings industry together in one place at one time, twice a year. The purpose is to help all the stakeholders to make more profitable connections, and create even better events, meetings and experiences. In the vibrant shows meeting planners can walk through the world in a day, keep up to date with the latest industry developments and ideas, and find all the suppliers they need under one roof. IMEX America is designed for meeting and events professionals, association executives, incentive travel buyers or an in-house event expert to find all the suppliers needed for the eventsfrom new venues in major cities across the world to the latest event tech providers. For exhibitors, exhibiting at IMEX America means you'll meet decision makers with real buying power in one of the biggest meetings markets in the world. Much more than just a trade show, IMEX America offers brilliant speakers, fresh ideas and continuous inspiration at 180-plus educational and networking events over four days.

Smart Monday is a complimentary day of education on Monday before IMEX America officially begins. Complimentary cutting-edge professional development is open to all IMEX America buyers and sellers. MPI will feature nearly 30 education sessions covering topics such as risk management, medical meetings, contracts, strategic communications, and behavioral science. The majority of the education sessions is aligned to the CMP International Standards and is eligible for clock hours. It is the opportunity to immerse the participants in a full day of free education and networking before the show opens. From the headline keynote through in-depth deep dives to practical workshops, the expertled education program is focused on the professional development. Everyone can make his way between sessions step into the Smart Monday carnival experience. If you're registered for IMEX America you're welcome at Smart Monday. You only need to register separately for specialist education such as the Association Leadership Forum and Executive Meeting Forum. There are 6 different forums designed for different participants. See table V.
TABLE V. SMART MONDAY EDUCATION SESSIONS

\begin{tabular}{|c|c|}
\hline Item No. & Smart Monday Education Sessions \\
\hline 1 & Association Leadership Forum \\
\hline 2 & MPI keynotes \\
\hline 3 & Executive Meeting Forum \\
\hline 4 & SMM and Procurement Leadership Forum \\
\hline 5 & Meeting Management Forum \\
\hline 6 & IMEX-MPI-MCI Future Leaders Forum \\
\hline
\end{tabular}

Association Leadership Forum is a free education and networking program exclusively for association leadership and is created by ASAE, The Center for Association Leadership. The aim is to enable association leaders to thrive in the current disruptive business environment, ensuring your association is nimble enough to get results in a competitive landscape. Learn from engaging thought leaders, through strategic conversations and collaborative peer learning. MPI keynotes from outstanding speakers for daily inspiration. For example, on Smart Monday, IMEX America held on 16 - 18 October, 2018 in Sands Expo, Las Vegas, USA, Julius Solaris explores the legacy created by events, showing you how to turn your events into life-changing experiences. Tuesday sees Kelly McDonald explain how to lead (and thrive) in a diverse workforce. Wednesday Paul Smith sets out why storytelling can help you lead change and inspire innovation. Expect the unexpected on Thursday as you explore audience connection with C2. Executive Meeting Forum is a two-track education and networking exclusively for corporate executives. It is the opportunity to join your peers to explore and challenge industry norms and current ways of doing business. Learn from best-in-class corporate meetings and events practices and innovations. SMM and Procurement Leadership Forum are for in-depth discussion on key aspects of SMM program-from vendor management to procurement strategy. This is for those who are responsible for a global or regional meetings program. Meeting Management Forum is to share operational challenges and successes, from how to lead a global team to managing stakeholders. This is for those who are responsible for managing internal and extemal global teams with responsibility for high-level events. Last one is the IMEX-MPI-MCI Future Leaders Forum. This is the event for talented students considering a career in the meetings industry. If you're entering your final year of a hospitality, event or tourism management course, the Future Leaders Forum is a unique and free opportunity for you to gain expert insight into the meetings industry, learning from and connecting with inspirational industry experts and fellow students. Over the two-day program, you'll make valuable industry contacts, benefit from high-quality education and visit one of the biggest meetings markets in the world. The Forum is run in partnership with MPI and MCI. Therefore, all participants can find an event or education session to tap into event tech, polish your professional skills, spark your imagination at a groundbreaking keynote, or connect with your peers. The unique and free program has it covered.

\section{World Education Congress (WEC)}

The World Education Congress is MPI's signature event through which it delivers premier education, business and networking opportunities for meeting and event planners. 
Every programming decision made by MPI is toward the goal of revitalizing the participants and the events you plan. WEC aimed at designing the education experience all about and for its member and what they need to be successful. And that means the participant is in charge of his experience. Sessions start and end in different rotations in an open village floorplan, encouraging exploration and making things a little more exciting. Educational program is entirely up to the attendees. MPI education helps its member to plan events and their future. Through the MPI Academy and MPI events, all participants have access to cutting-edge education and event planning certification programs that enhance critical job skills. Delivered online and in-person throughout the year, MPI's education is open to event planning professionals of all levels. So, whether you're obtaining crucial clock hours toward your CMP or CAE, growing your knowledge base or simply staying sharp, MPI education is perfect for the job you have or the job you want.

\section{CONCLUSION}

As a leading world meeting and event industry association, MPI provides services for its member specially by designing the education sessions and learning experience, benefits them in term learning, networking and leadership development. MPI designs the education session based on the needs and expectations of its stakeholders, considering what to learn and what type of learning will be taking place. MPI education session design meets the requirement of meeting value measurement of learning in three areas. First is the learning environment. MPI tries to include factors relating to structure, design, setting as well as learner readiness and follow-up. The second is the learning process which includes stages of the process to the depth of learning taking place; the last one is how learning into action which helps to identify the value of the 'what next?' How much of the learning will be acted upon or adapted? MPI education sessions are very powerful and helpful because MPI research based on these measurement factors in advance about the learners and what types of design and structure might support the outcome. Learn, network, connect with the global meetings industry Inspirational exhibitors, fresh ideas from experts and innovators, countless networking opportunities, these are the typical features of MPI. With the efforts of MPI, connectors are connected so they can produce experiences that inspire, educate and energize. Because MPI believes that when people meet, they can think in ways previously unthought, they can break barriers and they can finally change the world and these are the ultimate objectives of meeting and event industry association MPI, Meeting Professional International.

\section{ACKNOWLEDGMENT}

This research was supported by the Tourism Management Discipline Research Program funded by Shanghai Polytechnic University, P.R. China (Grant NO. XXKPY1607).

\section{REFERENCES}

[1] Find Facilities, Successful Meetings 2018 "Meeting Trends: Successful Meetings".

[2] Events Industry Council, Oxford Economics, "Economic Significance of Meetings to the US Economy” February 2018.

[3] Meeting Value Research, "Measuring Meeting Value Guidebook” 2018.

[4] Roy Glen, Christy Suciu, Christopher Baughn, "The Need for Design Thinking in Business Schools - A Review, Academy of Management Learning \& Education, Vol. 13, No. 4, PP 653-667., 2014.

[5] Hon, A. H., Bloom, M., \& Crant, J. M.,” Overcoming resistance to change and enhancing creative performance. Journal of Management, 40 919-941, 2014.

[6] George G. Fenich, "Meetings, Expositions, Events, and Conventions, An Introduction to the Industry", third edition, Prentice Hall, Pearson, 2012.

[7] Barbara C. Nichols, "Professional Meeting Management" fifth edition, published by PCMA, 2010. 